\title{
Rhodococcus kyotonensis sp. nov., a novel actinomycete isolated from soil
}

\author{
Correspondence \\ Bing Li \\ aa67047@mail.ecc.u-tokyo.ac.jp
}

\author{
Bing Li, Keiko Furihata, Lin-Xian Ding and Akira Yokota
}

Institute of Molecular and Cellular Biosciences, The University of Tokyo, Yayoi 1-1-1, Bunkyo-ku, Tokyo 113-0032, Japan

\begin{abstract}
A polyphasic study was undertaken to establish the taxonomic position of an isolate, strain DS472 ${ }^{\top}$, from soil in Kyoto, Japan. Phylogenetic analysis, based on the $16 \mathrm{~S}$ rRNA gene sequences, revealed that this strain constitutes a new subline within the genus Rhodococcus, with Rhodococcus yunnanensis YIM $70056^{\top}$ and Rhodococcus fascians DSM $20669^{\top}$ as its nearest phylogenetic neighbours (98.2 and $97.8 \%$ sequence similarity, respectively). DNA-DNA hybridization experiments revealed 36 and $29 \%$ relatedness between the isolate and its phylogenetic relatives, $R$. yunnanensis and $R$. fascians, respectively. Chemotaxonomic characteristics, including the major quinone $M K-8\left(\mathrm{H}_{2}\right)$, predominant fatty acids $\mathrm{C}_{16: 0,}, \mathrm{C}_{18: 1} \omega 9 \mathrm{c}$ and 10-methyl $\mathrm{C}_{18: 0}$, the presence of cell-wall chemotype IV and mycolic acids, were consistent with the properties of members of the genus Rhodococcus. The DNA G +C content was $64.5 \mathrm{~mol} \%$. On the basis of both phenotypic and genotypic evidence, strain DS472 ${ }^{\top}$ represents a novel species of the genus Rhodococcus, for which the name Rhodococcus kyotonensis sp. nov. is proposed. The type strain is strain DS472 $\left(=\right.$ IAM $15415^{\top}=$ CCTCC AB206088 $\left.^{\top}\right)$.
\end{abstract}

The improved classification of the genus Rhodococcus provides a sound framework for the recognition and description of additional Rhodococcus species (Goodfellow et al., 1998, 1999). At the time of writing, the genus Rhodococcus was composed of 26 species with validly published names, including the recently described Rhodococcus imtechensis (Ghosh et al., 2006) and Rhodococcus kroppenstedtii (Mayilraj et al., 2006).

Strain DS472 ${ }^{\mathrm{T}}$ was isolated from a soil sample in Kyoto city, Japan and grown on nutrient agar (Difco) medium. The plates were incubated at $27{ }^{\circ} \mathrm{C}$ for 3 weeks. Single colonies from the plates were purified by transferring them onto new plates. Strain DS472 ${ }^{\mathrm{T}}$ was one of the isolated colonies and was used in this study. Strain $\mathrm{DS}_{472^{\mathrm{T}}}$ was maintained on a trypticase soy agar (TSA; BBL) slant at $4{ }^{\circ} \mathrm{C}$ and as a glycerol suspension sample $(20 \%$, v/v) at $-20{ }^{\circ} \mathrm{C}$. Cell morphology was observed by light microscopy (BX60; Olympus). For phenotypic properties, the growth range for temperature and $\mathrm{pH}$ were tested on yeast extract-malt extract ISP2 medium (Shirling \& Gottlieb, 1966), the $\mathrm{pH}$ range was tested with $\mathrm{pH}$ values ranging from 5.0 to 11.0 . For $\mathrm{pH} 5.0-7.5$, the $\mathrm{pH}$ was adjusted by the addition of $1 \mathrm{M} \mathrm{HCl}$ after adding $1 \mathrm{~g} \mathrm{NaHCO}_{3} \mathrm{l}^{-1}$. For

Abbreviation: DAP, diaminopimelic acid.

The GenBank/EMBL/DDBJ accession number for the 16S rRNA gene sequence of strain DS472 ${ }^{\top}$ is AB269261.

The characteristics that distinguish strain DS472 ${ }^{\top}$ from the closely related species of the genus Rhodococcus are presented in a supplementary table available with the online version of this paper.
pH 8.0-11.0, different amounts of carbonate were used. Catalase activity was determined by $3 \% \mathrm{H}_{2} \mathrm{O}_{2}$, and bubble production was identified as a positive reaction. Oxidase was determined by cytochrome oxidase paper (Nissui Pharmaceutical). Tolerance of salinity was determined by inoculating the strains into ISP2 medium supplemented with $0-12 \%(\mathrm{w} / \mathrm{v}) \mathrm{NaCl}$ at $1 \%$ intervals. API $50 \mathrm{CH}$, API $20 \mathrm{E}$ and API ZYM strips (bioMérieux) were used to determine physiological and biochemical characteristics according to the manufacturer's instructions.

For cellular fatty acid analysis, the strain was grown on TSA (BBL) at $27{ }^{\circ} \mathrm{C}$ for 3 days, and fatty acid methyl esters were prepared and identified using the Microbial Identification System as described by Xie \& Yokota (2003). For other chemotaxonomic analyses, freeze-dried cells were obtained from cultures grown in trypticase soy broth (TSB; BBL) at $27{ }^{\circ} \mathrm{C}$ for 5 days. The amino acid composition and isomers of diaminopimelic acid (DAP) in the cell walls were examined by two-dimensional TLC (Tokyo Kasei Co.) as described by Harper \& Davis (1979), and by HPLC according to procedures described by Yokota et al. (1993). The alkaline methanolysis procedure was used to detect mycolic acids (Minnikin et al., 1980) and whole-cell sugars were analysed by TLC (Yokota \& Takashima, 2001). Respiratory quinones were extracted from dried cells (300 mg) using chloroform/methanol $(2: 1)$ and were purified by TLC. The purified respiratory quinones were analysed by reverse-phase HPLC (Komagata \& Suzuki, 1987). The DNA G $+C$ content was determined by HPLC as described by Mesbah et al. (1989). 
An approximately $1500 \mathrm{bp}$ fragment of the 16S rRNA gene sequence was amplified by PCR and sequenced as described by Xie \& Yokota (2003). The 16S rRNA gene sequence of strain $\mathrm{DS} 472^{\mathrm{T}}$ was compared with the sequences obtained from GenBank and aligned by using the CLUSTAL_X software package (Thompson et al., 1997), evolutionary distances and the $K_{\text {nuc }}$ value (Kimura, 1980) were calculated. Alignment gaps and ambiguous bases were not taken into consideration in the calculations. A phylogenetic tree based on a comparison of 1210 bases was constructed using the neighbour-joining method (Saitou \& Nei, 1987). The topology of the tree was evaluated by using the bootstrap resampling method of Felsenstein (1985) with 1000 replicates, whereas similarity values were calculated by using MEGA3 (Kumar et al., 2004). DNA-DNA hybridization was performed by using the photobiotin-labelled probes in microplate wells, as described by Ezaki et al. (1989), and using a multi-well plate reader (CytoFluoR; PerSeptive Biosystems). The experiment was performed with two replications for each sample and the DNA relatedness values were calculated as the mean of the two values.

Phylogenetic analysis suggests that the isolate belongs within the genus Rhodococcus and clustered with Rhodococcus fasciens and Rhodococcus yunnanensis (Fig. 1). Comparison of almost-complete $16 \mathrm{~S}$ rRNA gene sequence $(1420 \mathrm{nt})$ showed that strain DS472 ${ }^{\mathrm{T}}$ shared the highest similarities with the sequences of $R$. yunnanensis YIM
$70056^{\mathrm{T}}(98.2 \%)$ and $R$. fascians DSM $20669^{\mathrm{T}}(97.8 \%)$. DNA-DNA hybridization experiments revealed 36 and $29 \%$ relatedness between the isolate and its phylogenetic relatives, $R$. yunnanensis and $R$. fasciens, respectively, which is below the $70 \%$ cut-off point recommended for the delineation of bacterial species by Wayne et al. (1987).

Chemotaxonomic analysis further supported the phylogenetic results. Cell wall analysis by HPLC and TLC indicated that glutamic acid, alanine and meso-DAP occur in a molar ratio of $1: 2: 0.6$; whole-cell hydrolysates were rich in arabinose and galactose (cell wall chemotype IV sensu Lechevalier \& Lechevalier, 1970). These results are consistent with the properties of the genus Rhodococcus (Goodfellow, 1986). Moreover, strain DS472 ${ }^{\mathrm{T}}$ could be distinguished from the other species of the genus Rhodococcus by various phenotypic data, as shown in Supplementary Table S1 (available in IJSEM Online) and Table 1. Other characteristics are given in the species description. On the basis of phenotypic, chemotaxonomic and genotypic characteristics, it is proposed that strain $\mathrm{DS}_{472}{ }^{\mathrm{T}}$ represents a novel species of the genus Rhodococcus, for which the name Rhodococcus kyotonensis sp. nov. is proposed.

\section{Description of $\boldsymbol{R h o d o c o c c u s ~ k y o t o n e n s i s ~ s p . ~ n o v . ~}$}

Rhodococcus kyotonensis (kyo.to.nen'sis. N.L masc. adj. kyotonensis pertaining to Kyoto, the source of soil from which the organism was isolated).

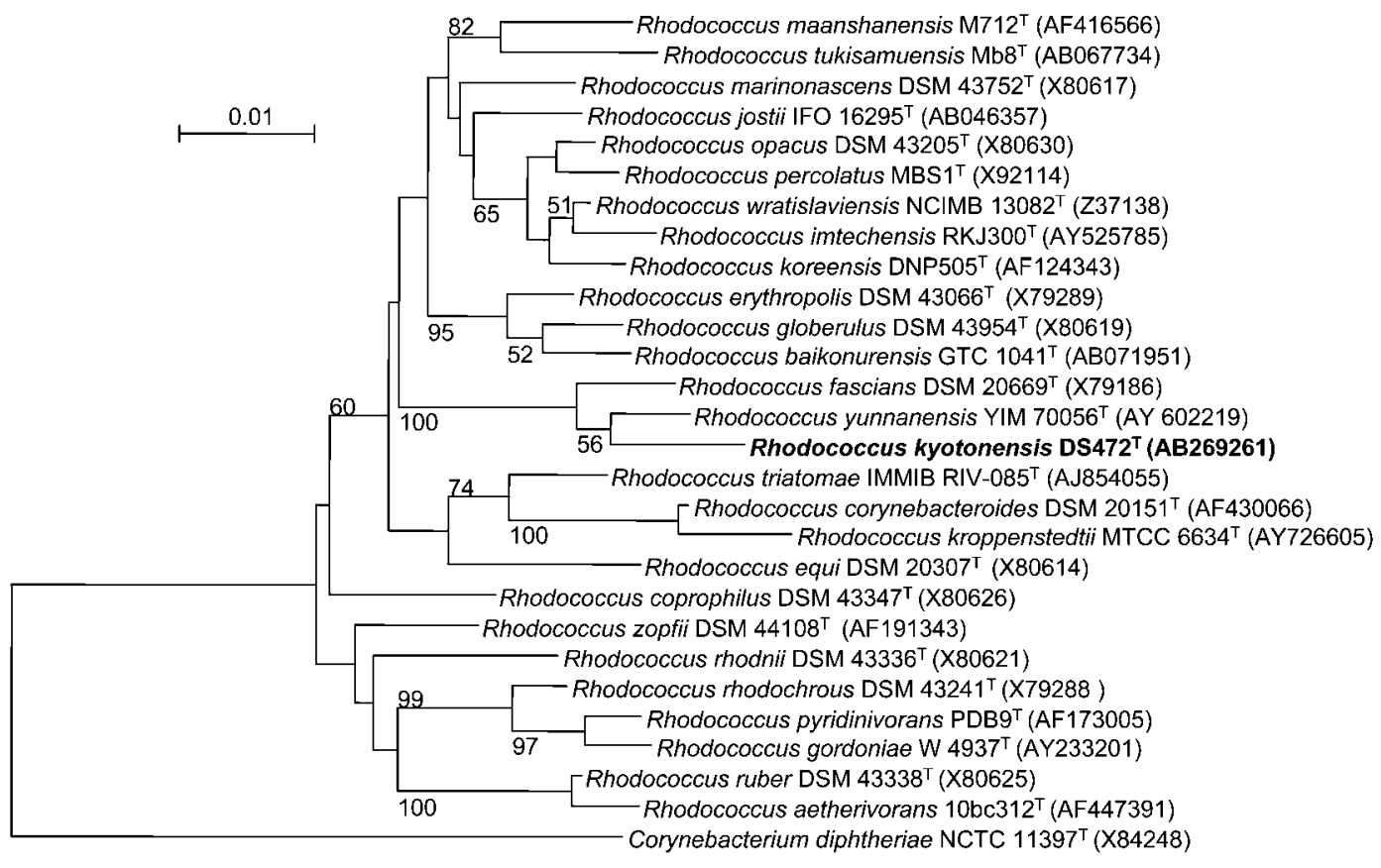

Fig. 1. Neighbour-joining phylogenetic tree based on the 16S rRNA gene sequences showing the relationship between strain DS $472^{\top}$ and representatives of the genus Rhodococcus. Numbers at nodes are bootstrap values based on 1000 resamplings; only values greater than $50 \%$ are shown. Bar, $0.01 K_{\text {nuc }}$. 
Table 1. Comparison of phenotypic characteristics between strain $D S 472^{\top}$ and its most closely related species of the genus Rhodococcus

+ , Positive; -, negative.

\begin{tabular}{|c|c|c|c|}
\hline Characteristic & DS472 ${ }^{\mathrm{T}}$ & $\begin{array}{c}\text { R. yunnanensis IAM } \\
15239^{\mathrm{T}}\end{array}$ & $\begin{array}{c}\text { R. fascians IAM } \\
12427^{\mathrm{T}}\end{array}$ \\
\hline Growth temperature $\left({ }^{\circ} \mathrm{C}\right)$ & $10-37$ & $10-40$ & $15-37$ \\
\hline Highest $\mathrm{NaCl}$ tolerance $(\% ; \mathrm{w} / \mathrm{v})$ & 9 & 10 & 9 \\
\hline \multicolumn{4}{|l|}{ Enzyme assay (API ZYM) } \\
\hline Esterase lipase & + & - & - \\
\hline Valine arylamidase & + & - & + \\
\hline Cystine arylamidase & + & - & - \\
\hline Acid phosphatase & + & - & + \\
\hline$\beta$-Glucuronidase & - & + & - \\
\hline$\alpha$-Galactosidase & - & + & - \\
\hline$\beta$-Galactosidase & - & + & - \\
\hline$\beta$-Glucosidase & - & + & - \\
\hline$N$-Acetyl- $\beta$-glucosaminidase & - & + & - \\
\hline Naphthol-AS-BI-phosphohydrolase & + & - & + \\
\hline
\end{tabular}

Gram-positive, non-motile, non-spore-forming and acidfast actinomycete that forms non-branching hyphae which fragment into short rod-to-coccus elements. Colonies on TSA medium are yellow-orange-pigmented, smooth and opaque. Growth occurs well over a pH range (6.0-8.0) on the ISP2 medium; the optimal $\mathrm{pH}$ for growth is around 7.0. The temperature range for growth is $10-37{ }^{\circ} \mathrm{C}$; with optimal growth temperature of $27-30{ }^{\circ} \mathrm{C}$, growth cannot occur at $40{ }^{\circ} \mathrm{C}$. The $\mathrm{NaCl}$ tolerance range is up to $9 \%$. Catalase activity is positive, whereas oxidase activity is negative. Hydrolyses Tweens 20, 40, 60 and 80. Gelatin hydrolysis, citrate utilization, activities of ONPG, arginine dihydrolase, lysine decarboxylase, ornithine decarboxylase, production of hydrogen sulfide and indole, and reduction of nitrate and nitrite are negative. Positive results for the activities of esterase lipase (C8), leucine arylamidase, valine arylamidase, cystine arylamidase, acid phosphatase, $\alpha$ glucosidase, urease, tryptophan deaminase, hydrolysis of aesculin and Voges-Proskauer test, but negative results for alkaline phosphatase, esterase (C4), lipase (C4), trypsin, chymotrypsin, naphthol-AS-BI-phosphohydrolase, $\alpha$ galactosidase, $\beta$-galactosidase, $\beta$-glucuronidase, $\beta$-glucosidase, $\quad N$-acetyl- $\beta$-glucosamidase, $\alpha$-mannosidase and $\alpha$-fucosidase. Utilizes glycerol, glucose, ribose, galactose, fructose, sorbose, rhamnose, myo-inositol, mannitol, sorbitol, sucrose, xylitol, D-arabitol, and gluconate as the sole carbon and energy sources, but erythritol, D-arabinose, L-arabinose, D-xylose, L-xylose, adonitol, methyl $\beta$-D-xyloside, mannose, dulcitol, methyl $\alpha$-D-mannoside, methyl $\alpha$ D-glucoside, $N$-acetyl-D-glucosamine, amygdalin, arbutin, salicin, cellobiose, maltose, lactose, melibiose, trehalose, inulin, melezitose, raffinose, starch, glycogen, gentiobiose, D-turanose, D-lyxose, D-tagatose, D-fucose, L-fucose, Larabitol, 2-keto-gluconate and 5-keto-gluconate are not utilized. Diamino acid in the peptidoglycan is meso-DAP; arabinose and galactose dominate in the whole-cell hydrolysates (wall type IV). The percentage of major menaquinone $\mathrm{MK}-8\left(\mathrm{H}_{2}\right)$ is $94.6 \%$, minor menaquinones MK-7 $\left(\mathrm{H}_{2}\right)$ and $\mathrm{MK}-9\left(\mathrm{H}_{2}\right)$ is 2.8 and $2.6 \%$, respectively. Mycolic acids are present, which co-migrate with those of the type strain of $R$. rhodochrous. The fatty acids are $\mathrm{C}_{16: 0}$ (40.8\%), $\mathrm{C}_{18: 1} \omega 9 c(18.1 \%)$, 10-methyl $\mathrm{C}_{18: 0}(17.5 \%)$, $\mathrm{C}_{14: 0}(7.2 \%)$, iso- $\mathrm{C}_{15: 0} 2-\mathrm{OH} / \mathrm{C}_{16: 1} \omega 7 c(5.5 \%)$ and $\mathrm{C}_{15: 0}$ $(2.1 \%)$. The DNA G $+\mathrm{C}$ content is $64.5 \mathrm{~mol} \%$.

The type strain, DS472 ${ }^{\mathrm{T}} \quad\left(=\mathrm{IAM} \quad 15415^{\mathrm{T}}=\mathrm{CCTCC}\right.$ $\mathrm{AB} 206088^{\mathrm{T}}$ ), was isolated from the soil in Kyoto city, Japan.

\section{References}

Ezaki, T., Hashimoto, Y. \& Yabuuchi, E. (1989). Fluorometric deoxyribonucleic acid-deoxyribonucleic acid hybridization in microdilution wells as an alternative to membrane filter hybridization in which radioisotopes are used to determine genetic relatedness among bacterial strains. Int J Syst Bacteriol 39, 224-229.

Felsenstein, J. (1985). Confidence limits on phylogenies: an approach using the bootstrap. Evolution 39, 783-791.

Ghosh, A., Paul, D., Prakash, D., Mayilraj, S. \& Jain, R. K. (2006). Rhodococcus imtechensis sp. nov., a nitrophenol-degrading actinomycete. Int J Syst Evol Microbiol 56, 1965-1969.

Goodfellow, M. (1986). Genus Rhodococcus Zopf 1891, 28AL. In Bergey's Manual of Systematic Bacteriology, vol. 2, pp. 1472-1481. Edited by P. H. A. Sneath, N. S. Mair, M. E. Sharpe \& J. G. Holt. Baltimore: Williams \& Wilkins.

Goodfellow, M., Alderson, G. \& Chun, J. (1998). Rhodococcal systematics: problems and developments. Antonie Van Leeuwenhoek 74, 1-12.

Goodfellow, M., Isik, K. \& Yates, E. (1999). Actinomycete systematics: an unfinished synthesis. Nova Acta Leopold 312, 47-82.

Harper, J. J. \& Davis, G. H. G. (1979). Two-dimensional thin-layer chromatography for amino acid analysis of bacterial cell walls. Int $J$ Syst Bacteriol 29, 56-58.

Kimura, M. (1980). A simple method for estimating evolutionary rates of base substitutions through comparative studies of nucleotide sequences. J Mol Evol 16, 111-120. 
Komagata, K. \& Suzuki, K. (1987). Lipid and cell-wall analysis in bacterial systematics. Methods Microbiol 19, 161-207.

Kumar, S., Tamura, K. \& Nei, M. (2004). MEGA3: integrated software for molecular evolutionary genetics analysis and sequence alignment. Brief Bioinform 5, 150-163.

Lechevalier, M. P. \& Lechevalier, H. A. (1970). Chemical composition as a criterion in the classification of aerobic actinomycetes. Int J Syst Bacteriol 20, 435-443.

Mayilraj, S., Krishnamurthi, S., Saha, P. \& Saini, H. S. (2006). Rhodococcus kroppenstedtii sp. nov., a novel actinobacterium isolated from a cold desert of the Himalayas, India. Int J Syst Evol Microbiol 56, 979-982.

Mesbah, M., Premachandran, U. \& Whitman, W. B. (1989). Precise measurement of the $\mathrm{G}+\mathrm{C}$ content of deoxyribonucleic acid by highperformance liquid chromatography. Int J Syst Bacteriol 39, 159-167.

Minnikin, D. E., Hutchinson, I. G., Caldicott, A. B. \& Goodfellow, M. (1980). Thin-layer chromatography of methanolysates of mycolic acid-containing bacteria. J Chromatogr 188, 221-233.

Saitou, N. \& Nei, M. (1987). The neighbor-joining method: a new method for reconstructing phylogenetic trees. Mol Biol Evol 4, $406-425$.
Shirling, E. B. \& Gottlieb, D. (1966). Methods for characterization of Streptomyces species. Int J Syst Bacteriol 16, 313-340.

Thompson, J. D., Gibson, T. J., Plewniak, F., Jeanmougin, F. \& Higgins, D. G. (1997). The CLUSTAL_X windows interface: flexible strategies for multiple sequence alignment aided by quality analysis tools. Nucleic Acids Res 25, 4876-4882.

Wayne, L. G., Brenner, D. J., Colwell, R. R., Grimont, P. A. D., Kandler, O., Krichevsky, M. I., Moore, L. H., Moore, W. E. C., Murray, R. G. E. \& other authors (1987). International Committee on Systematic Bacteriology. Report of the ad hoc committee on reconciliation of approaches to bacterial systematics. Int J Syst Bacteriol 37, 463-464.

Xie, C.-H. \& Yokota, A. (2003). Phylogenetic analyses of Lampropedia hyalina based on the 16S rRNA gene sequence. J Gen Appl Microbiol 49, 345-349.

Yokota, A. \& Takashima, M. (2001). Cell wall. In Classification and Identification of Microorganisms, pp. 97-117. Edited by K. Suzuki, A. Hiraishi \& A. Yokota. Tokyo: Springer-Verlag (in Japanese).

Yokota, A., Tamura, T., Nishii, T. \& Hasegawa, T. (1993). Kineococcus aurantiacus gen. nov., sp. nov., a new aerobic gram-positive, motile coccus with meso-diaminopimelic acid and arabinogalactan in the cell wall. Int J Syst Bacteriol 43, 52-57. 